\title{
A Review of E-Financial Reporting Research
}

\author{
Mohd Noor Azli Ali Khan ${ }^{1}$ and Noor Azizi Ismail ${ }^{2}$ \\ ${ }^{1}$ Management Department, Faculty of Management and Human Resource Development, \\ Universiti Teknologi Malaysia \\ ${ }^{2}$ College of Business, Universiti Utara Malaysia
}

\begin{abstract}
Internet is a very exciting medium to look into especially with regards to presentation, disclosure and financial reporting. The Internet also has become one of users' most frequently used sources of information. Consistent with the innovation of the Internet as a cheap but powerful communication device, disclosure of financial and non-financial information on the Internet is becoming an increasingly popular subject of research. Internet reporting or e-reporting is a very powerful and useful tool for financial reporting information. Internet Financial Reporting (IFR) has become quite a trendy practice of communicating with stakeholders in recent times. World Wide Web (WWW) technologies are extensively used by ever-increasing number of companies around the world. A growing percentage of those companies have created and promoted websites on the Internet. There have been tendencies to disseminate information on their websites, including financial data, financial performance, social and environmental issues, corporate information, corporate governance, marketing and other information. At this point, a significant amount of academic research has been established in the area of IFR in developed countries such as the United States, United Kingdom and other European countries. On the contrary, very few studies are carried out in developing countries. Previous IFR studies are divided into three main groups: single-country studies, multi-country studies and international studies. Methodologically, studies on IFR are categorized into three main groups: descriptive research, comparative research and explanatory research. This paper seeks to contribute to the existing body of knowledge concerning online financial reporting by reviewing and documenting the research of IFR.
\end{abstract}

Keywords: Internet financial reporting, descriptive studies, relationship studies and dimension.

\section{Introduction}

The Internet, being the fastest mode of communication, multidirectional in nature and very fast in transmission (Sanchez et al., 2011), has the widest reach in the present world of globalized economics (Garg \& Verma, 2010) and can be a powerful tool for building shareholder value (Seetharaman \&

Subramaniam, 2005/2006). The Internet also is a unique information disclosure tool that encourages flexible forms of presentation and allows immediate, broad, and inexpensive communication to

Copyright (c) 2012 Mohd Noor Azli Ali Khan and Noor Azizi Ismail. This is an open access article distributed under the Creative Commons Attribution License unported 3.0, which permits unrestricted use, distribution, and reproduction in any medium, provided that original work is properly cited. Contact author: Mohd Noor Azli Ali Khan E-mail: m-nazli@utm.my 
investors (Kelton \& Yang, 2008). Furthermore, the Internet also provides a unique form of corporate voluntary disclosure that enables companies to provide information instantaneously to global audience (Abdelsalam, Bryant \& Street, 2007). Moreover, the Internet enables companies to voluntarily communicate share prices, preliminary announcements, press conferences, and other information via email and web casts to a large global audience of current and perspective investors (Abdelsalam \& Street, 2007).

Using the Internet allows a company to provide on-line a large volume of information which users can access on demand, in function of their particular area of interest (Bonson \& Escobar, 2006). Also, corporate information on the Internet provides benefits in cost-cutting, distribution, frequency and speed (Gandia, 2008). In the present global era, the use of Internet in financial reporting plays a significant role in the market (Al Arussi et al., 2009) and forming investors worldwide (Abdelsalam \& Street, 2007). In relation to the Internet as a medium for disclosure, the management can reduce the agency problem and alleviate information asymmetry due to its unlimited space, wide coverage, easyaccess report, and real-time information (Al Arussi et al, 2009). Internet financial reporting (herein after known as IFR) has become quite a popular practice of communicating with stakeholders in recent times. Therefore, research on the evolution of it is considered relevant to public. Therefore, this paper aims to examine and synthesize the previous studies on IFR research.

The remainder of this paper is organized as follows: the next section provides a review of the literature on IFR research and describes the categorization of IFR. The following section describes the descriptive studies, association studies, dimension of IFR and timeliness of IFR. Conclusions are drawn in the last section.
This section should follow keywords. This section should provide background of the study and highlight research motivation.

\section{Review of Literature on IFR}

Literature in relation to financial reporting on the Internet is growing (Oyelere et al, 2003). In recent years, Internet usage has significantly impacted companies' corporate reporting practices (Khadaroo, 2005) and the issue of IFR has been the subject of attention of a number of researchers (Chatterjee \& Hawkes, 2008). There are lots of IFR researches. The growing use of the Internet for corporate dissemination, including providing annual reports on the Internet, and the extent and sophistication of IFR practices vary across countries (Mohamed et al., 2009). In general, the research of IFR can be divided into several themes, as follows: descriptive research, comparative research and explanatory research (Pervan, 2006). Furthermore, most researchers include a comprehensive set of financial statements and financial highlights extracted from the statements in their corporate website to qualify as IFR company (Ali Khan, 2010; Ali Khan \& Ismail, 2011).

\section{Categorization of IFR}

An extensive review of the literature reveals that several studies have looked into IFR and could be classified into two themes (Hassan et al., 1999). Hassan et al. (1999) categorize IFR research that examine (1) the practice of companies for reporting purpose and investor relations (IR) communication strategy; and (2) the determinants of Web-based disclosure policy choice. Moreover, the literature in IFR area can be classified into two themes: (1) the practices of companies using the Internet for financial reporting purposes and as an investor relations communication strategy; and (2) the determinants of web-based disclosure 
policy choice (Joshi \& Al-Modhahdki, 2003). Furthermore, the research on web reporting can be divided into two main categories: descriptive research and explanatory research (Marston \& Polei, 2004; Garg \& Verma, 2010). Otherwise, the research on IFR can be divided into three main categories: descriptive research by one or more countries, research by professional bodies and explanatory research (Ali Khan, 2010).

A number of studies discuss the benefits of IFR, speculate on its future, and identify issues and concerns in relation to the use of such medium (Oyelere et al., 2003). Oyelere et al. (2003) find that some studies report on surveys on IFR practices in single countries while others undertake cross-country comparisons. Furthermore, literature in IFR field differentiates research for three main groups; single-country studies, multicountry studies and international studies (Celik et al., 2006). A few studies examine the corporate characteristics associated with the choice of Internet corporate financial reporting (Oyelere et al., 2003).
The extent of the studies on corporate internet reporting (CIR) can be categorized as either descriptive studies or association studies (Abdelsalam et al., 2007). Abdelsalam et al. (2007) explain that descriptive research focus on providing statistics on how many items of given disclosure checklist are disclosed/provided. Otherwise, association research (i.e., providing evidence of independent variables associated with the level of disclosure) emphasizes the determinants of CIR (Abdelsalam et al., 2007).

In summary, several prior studies describe IFR disclosure and presentation in specific countries or listed companies on specific stock exchanges. Additionally, as summarized in Table 1, evidence links several firm specific characteristics with the level of IFR disclosure. These include the size of the firm, which appears to be positively associated with the disclosure on the Internet. Also, evidence on other variables examined is largely inconclusive. 
Table 1: Summary of Selected Empirical Studies Addressing Determinants of Internet Financial Reporting

\begin{tabular}{|c|c|c|c|c|c|c|}
\hline No. & Authors & $\begin{array}{l}\text { Date of Data } \\
\text { Collection }\end{array}$ & Sample & $\begin{array}{l}\text { Number of } \\
\text { Checklist } \\
\text { Items }\end{array}$ & Dependent Variables & $\begin{array}{c}\text { Significant } \\
\text { Independent } \\
\text { Variables }\end{array}$ \\
\hline 1 & $\begin{array}{l}\text { Marston and } \\
\text { Leow (1998) }\end{array}$ & $\begin{array}{l}\text { November } \\
1996\end{array}$ & U.K. FTSE-100 & 2 & $\begin{array}{l}\text { Presence of website } \\
\text { Disclosure of any financial } \\
\text { information on the website }\end{array}$ & Size $(+)$ \\
\hline 2 & $\begin{array}{l}\text { Ashbaugh et } \\
\text { al. (1999) }\end{array}$ & $\begin{array}{l}\text { November } \\
1997 \\
\text { through } \\
\text { January } \\
1998\end{array}$ & $\begin{array}{l}290 \text { U.S. } \\
\text { companies } \\
\text { (criticized by } \\
\text { AIMR) }\end{array}$ & 3 & $\begin{array}{l}\text { Website provides: } \\
\text { Comprehensive set of } \\
\text { financial statements } \\
\text { (including footnotes and } \\
\text { auditors report) } \\
\text { Link to annual report } \\
\text { elsewhere on Internet } \\
\text { Link to U.S. SEC's EDGAR } \\
\text { system }\end{array}$ & $\begin{array}{l}\text { Size (+) } \\
\text { Profitability (+) } \\
\text { AIMR highly } \\
\text { ranked firm (+) }\end{array}$ \\
\hline 3 & $\begin{array}{l}\text { Craven and } \\
\text { Marston } \\
\text { (1999) }\end{array}$ & July 1998 & $\begin{array}{l}206 \text { largest U.K. } \\
\text { companies }\end{array}$ & 2 & $\begin{array}{l}\text { Presence of website } \\
\text { Disclosure of any financial } \\
\text { information on website }\end{array}$ & Size (+) \\
\hline 4 & $\begin{array}{l}\text { Hassan et al. } \\
\text { (1999) }\end{array}$ & $\begin{array}{l}\text { Third } \\
\text { quarter } \\
1998\end{array}$ & $\begin{array}{l}247 \text { companies } \\
\text { listed on Kuala } \\
\text { Lumpur Stock } \\
\text { Exchange } \\
\end{array}$ & 2 & $\begin{array}{l}\text { Presence of website } \\
\text { (website with financial and } \\
\text { website with no financials) }\end{array}$ & $\begin{array}{l}\text { Size (+) } \\
\text { Profitability }(+)\end{array}$ \\
\hline 5 & $\begin{array}{l}\text { Pirchegger } \\
\text { and } \\
\text { Wagenhofer } \\
\text { (1999) }\end{array}$ & $\begin{array}{l}\text { December } \\
1997 \text { and } \\
\text { December } \\
1998\end{array}$ & $\begin{array}{l}\text { 26/20 Austrian } \\
\text { companies } \\
\text { 1998/ 1999 } \\
\text { German DAX-30 } \\
1998 \text { only }\end{array}$ & 38 & $\begin{array}{l}\text { 7-Content } \\
\text { 5-Timeliness } \\
\text { 14-Technology } \\
\text { 12-User support }\end{array}$ & $\begin{array}{l}\text { Size }(+) \\
\text { Free float }(+) \\
\text { (both for } \\
\text { Austrian } \\
\text { companies only) }\end{array}$ \\
\hline 6 & $\begin{array}{l}\text { Joshi and Al- } \\
\text { Bastaki } \\
\text { (2000) }\end{array}$ & $\begin{array}{l}\text { December } \\
1998\end{array}$ & $\begin{array}{l}35 \text { banks in } \\
\text { Bahrain }\end{array}$ & 3 & $\begin{array}{l}\text { Presence of website (Banks } \\
\text { having websites, banks } \\
\text { having no website and banks } \\
\text { providing accounts) }\end{array}$ & $\begin{array}{l}\text { Size (+) } \\
\text { Type of bank (+) } \\
\text { Profitability (+) }\end{array}$ \\
\hline 7 & $\begin{array}{l}\text { Ettredge et } \\
\text { al. (2001) }\end{array}$ & $\begin{array}{l}\text { February } \\
\text { through May } \\
1998\end{array}$ & $\begin{array}{l}402 \text { U.S. } \\
\text { companies (AIMR } \\
\text { rated, } \\
\text { biotechnology, } \\
\text { and computer } \\
\text { technology) }\end{array}$ & 17 & $\begin{array}{l}\text { 6-Accounting information } \\
\text { items } \\
\text { 11-Other financial } \\
\text { information items }\end{array}$ & $\begin{array}{l}\text { Size (+) } \\
\text { Industry } \\
\text { (petroleum } \\
\text { highest and } \\
\text { homebuilding } \\
\text { lowest) }\end{array}$ \\
\hline 8 & $\begin{array}{l}\text { Bonson and } \\
\text { Escobar } \\
(2002)\end{array}$ & $\begin{array}{l}\text { July and } \\
\text { August } 2001\end{array}$ & $\begin{array}{l}\text { The biggest } 20 \\
\text { companies of } \\
\text { each European } \\
\text { Union country }\end{array}$ & 23 & $\begin{array}{l}\text { Companies' transparency } \\
\text { (Financial aspect, other } \\
\text { financial and non-financial } \\
\text { and quantitative/ qualitative } \\
\text { variables) }\end{array}$ & $\begin{array}{l}\text { Size }(+) \\
\text { Sector }(+) \\
\text { Country of origin } \\
(+)\end{array}$ \\
\hline
\end{tabular}




\begin{tabular}{|c|c|c|c|c|c|c|}
\hline No. & Authors & $\begin{array}{l}\text { Date of Data } \\
\text { Collection }\end{array}$ & Sample & $\begin{array}{l}\text { Number of } \\
\text { Checklist } \\
\text { Items }\end{array}$ & $\begin{array}{l}\text { Dependent } \\
\text { Variables }\end{array}$ & $\begin{array}{l}\text { Significant Independent } \\
\text { Variables }\end{array}$ \\
\hline 9 & $\begin{array}{l}\text { Larran and Giner } \\
(2002)\end{array}$ & $\begin{array}{l}\text { October and } \\
\text { November } \\
2000\end{array}$ & $\begin{array}{l}144 \text { companies in } \\
\text { Madrid Stock } \\
\text { Exchange }\end{array}$ & Not specified & $\begin{array}{l}\text { Disclosure index } \\
\text { (Content and } \\
\text { accessibility } \\
\text { items) }\end{array}$ & Size (+) \\
\hline 10 & $\begin{array}{l}\text { Debreceny et al. } \\
\text { (2002) (IASC } \\
\text { sponsored) }\end{array}$ & $\begin{array}{l}\text { November } \\
1998 \text { through } \\
\text { February } 1999\end{array}$ & $\begin{array}{l}660 \text { large } \\
\text { companies in } 22 \\
\text { countries (30 } \\
\text { highest market } \\
\text { capitalization } \\
\text { companies listed in } \\
\text { each country in } \\
\text { Dow Jones Global } \\
\text { Index) }\end{array}$ & 2 & $\begin{array}{l}\text { 1-Presentation } \\
\text { (type of website) } \\
\text { 1-Content } \\
\text { (amount of } \\
\text { disclosure) }\end{array}$ & $\begin{array}{l}\text { For content: } \\
\text { Size (+) } \\
\text { U.S. listing (+) } \\
\text { Growth prospects / } \\
\text { intangibles (Market value } \\
\text { to book value) (-) } \\
\text { For presentation: } \\
\text { Size (+) } \\
\text { U.S. listing (+) } \\
\text { General cross listing (-) } \\
\text { Level of technology } \\
\text { (particularly being in } \\
\text { pharmaceutical industry) } \\
(+) \\
\text { Disclosure environment }\end{array}$ \\
\hline 11 & $\begin{array}{l}\text { Ettredge et al. } \\
(2002)\end{array}$ & $\begin{array}{l}\text { Late } 1997 \\
\text { through early } \\
1998\end{array}$ & $\begin{array}{l}193 \text { U.S. companies } \\
\text { (AIMR rated) }\end{array}$ & 16 & $\begin{array}{l}\text { 4-Financial } \\
\text { information items } \\
\text { required in SEC } \\
\text { filings } \\
\text { 12-Items of } \\
\text { voluntary } \\
\text { disclosure }\end{array}$ & $\begin{array}{l}\text { For both: } \\
\text { Size (+) } \\
\text { Correlation annual } \\
\text { earnings and returns (-) } \\
\text { For voluntary disclosure } \\
\text { only: } \\
\text { Raising equity capital (if } \\
\text { stock issued during } 1996 \\
\text { or 1997) (+) } \\
\text { Quality (AIMR measure) } \\
(+)\end{array}$ \\
\hline 12 & $\begin{array}{l}\text { Allam and Lymer } \\
\text { (2003) }\end{array}$ & $\begin{array}{l}\text { End of } 2001 \\
\text { and early } 2002\end{array}$ & $\begin{array}{l}250 \text { companies (50 } \\
\text { largest in advanced } \\
\text { capital markets; } \\
\text { U.S., U.K., Canada, } \\
\text { Australia, and H.K.) }\end{array}$ & 36 & $\begin{array}{l}\text { 12-General } \\
\text { attributes } \\
\text { 24-Financial / } \\
\text { Annual report } \\
\text { attributes }\end{array}$ & $\begin{array}{l}\text { Size (+) (only for } \\
\text { Australia) } \\
\text { Country (U.S., U.K., and } \\
\text { Canadian companies } \\
\text { close and leading / } \\
\text { Australian companies } \\
\text { follow with small gap / } \\
\text { H.K. lagged behind) }\end{array}$ \\
\hline 13 & $\begin{array}{l}\text { Joshi and Al- } \\
\text { Modhahki } \\
\text { (2003) }\end{array}$ & $\begin{array}{l}\text { October } 2002 \\
\text { to December } \\
2002\end{array}$ & $\begin{array}{l}75 \text { listed } \\
\text { companies from } \\
\text { Bahrain and } \\
\text { Kuwait Stock } \\
\text { Exchanges }\end{array}$ & 1 & $\begin{array}{l}\text { Presence of } \\
\text { website }\end{array}$ & $\begin{array}{l}\text { Size }(+) \\
\text { Industry }(+)\end{array}$ \\
\hline 14 & Marston (2003) & $\begin{array}{l}1998 \text { plus } \\
\text { follow up in } \\
\text { May } 2001\end{array}$ & $\begin{array}{l}99 \text { top Japanese } \\
\text { companies }\end{array}$ & 13 & $\begin{array}{l}\text { Whether company } \\
\text { had website } \\
\text { Whether any } \\
\text { English website } \\
\text { on homepage } \\
\text { Whether } 11 \text { items } \\
\text { of financial } \\
\text { information } \\
\text { disclosed on } \\
\text { website }\end{array}$ & $\begin{array}{l}\text { Size }(+) \\
\text { Industry (+) } \\
\text { (both related to existence } \\
\text { of website but not extent } \\
\text { of disclosure on web) }\end{array}$ \\
\hline
\end{tabular}




\begin{tabular}{|c|c|c|c|c|c|c|}
\hline No. & Authors & $\begin{array}{l}\text { Date of Data } \\
\text { Collection }\end{array}$ & Sample & $\begin{array}{l}\text { Number of } \\
\text { Checklist } \\
\text { Items }\end{array}$ & $\begin{array}{l}\text { Dependent } \\
\text { Variables }\end{array}$ & $\begin{array}{l}\text { Significant Independent } \\
\text { Variables }\end{array}$ \\
\hline 15 & Oyelere et al. (2003) & Not specified & $\begin{array}{l}229 \text { N.Z. } \\
\text { companies } \\
\text { (123 with } \\
\text { websites; } 90 \\
\text { included } \\
\text { Internet } \\
\text { financial } \\
\text { reporting) }\end{array}$ & 8 & $\begin{array}{l}\text { Financial and non- } \\
\text { financial } \\
\text { information } \\
\text { provided on } \\
\text { corporate website }\end{array}$ & $\begin{array}{l}\text { Size (+) } \\
\text { Liquidity (+) } \\
\text { Ownership spread } \\
\text { (higher the proportion of } \\
\text { shareholding by top } 40 \\
\text { percent of shareholders, } \\
\text { lower the probability of } \\
\text { disclosure) } \\
\text { Industry (primary } \\
\text { industry group sector: oil } \\
\text { and gas and forestry } \\
\text { highest) }\end{array}$ \\
\hline 16 & $\begin{array}{l}\text { Abdelsalam et al. } \\
(2004)\end{array}$ & July 2004 & $\begin{array}{l}30 \text { Indian } \\
\text { companies on } \\
\text { BSE Sensex }\end{array}$ & 114 & $\begin{array}{l}\text { 64-Content } \\
\text { 50-Usability }\end{array}$ & $\begin{array}{l}\text { For overall and content } \\
\text { disclosure: } \\
\text { Big } 4 \text { auditor (+) } \\
\text { Free float (+) } \\
\text { Gearing (-) } \\
\text { PE (profitability) (-) } \\
\text { U.S. listing/ filing (+) } \\
\text { Industry (manufacturing) } \\
\text { [overall only] (-) } \\
\text { None significant for } \\
\text { usability }\end{array}$ \\
\hline 17 & $\begin{array}{l}\text { Marston and Polei } \\
\text { (2004) }\end{array}$ & $\begin{array}{l}\text { July } 2000 \text { and } \\
\text { May/June } \\
2003\end{array}$ & $\begin{array}{l}50 \text { German } \\
\text { companies } \\
\text { (top quartile } \\
\text { and bottom } \\
\text { quartile of DAX } \\
100 \text { ) }\end{array}$ & $\begin{array}{l}53(2000) \\
71(2003)\end{array}$ & $\begin{array}{l}\text { Content (16- } \\
\text { Investor related, } \\
\text { accounting and } \\
\text { financial } \\
\text { information, 5- } \\
\text { Timeliness, 5- } \\
\text { Contact details, 14- } \\
\text { Corporate } \\
\text { governance, and 5- } \\
\text { Social } \\
\text { responsibility) } \\
\text { Presentation (10- } \\
\text { Technology, 6- } \\
\text { Navigation, 7- } \\
\text { Structure, and 3- } \\
\text { Contact and } \\
\text { information supply } \\
\text { services) }\end{array}$ & $\begin{array}{l}\text { For 2000: } \\
\text { Size }(+) \\
\text { Free float }(+) \\
\text { For 2003: } \\
\text { Size }(+) \\
\text { ROE }(-) \\
\text { Foreign listing }(+) \\
\text { State share ownership }(-)\end{array}$ \\
\hline 18 & Xiao et al. (2004) & August 2002 & $\begin{array}{l}300 \text { largest } \\
\text { Chinese-listed } \\
\text { companies } \\
\text { (203 had a } \\
\text { website) }\end{array}$ & 82 & $\begin{array}{l}\text { 58-Content } \\
\text { 24-Presentation }\end{array}$ & $\begin{array}{l}\text { For the } 2003 \text { with } \\
\text { website: } \\
\text { IT industry (+) } \\
\text { Size (+) } \\
\text { Legal person ownership } \\
(+) \\
\text { Leverage (+) } \\
\text { State share ownership (-) }\end{array}$ \\
\hline 19 & $\begin{array}{l}\text { Chan and } \\
\text { Wickramasinghe } \\
\text { (2006) }\end{array}$ & $\begin{array}{l}\text { August and } \\
\text { September } \\
2000\end{array}$ & $\begin{array}{l}\text { Australian } \\
\text { Stock } \\
\text { Exchange } \\
\text { (ASX) }\end{array}$ & 44 & $\begin{array}{l}\text { 17-Content, 10- } \\
\text { Timeliness, } \\
\text { 8-Technology, 9- } \\
\text { User support }\end{array}$ & Size $(+)$ \\
\hline
\end{tabular}




\begin{tabular}{|c|c|c|c|c|c|c|}
\hline No. & Authors & $\begin{array}{l}\text { Date of Data } \\
\text { Collection }\end{array}$ & Sample & $\begin{array}{l}\text { Number of } \\
\text { Checklist } \\
\text { Items }\end{array}$ & Dependent Variables & $\begin{array}{l}\text { Significant } \\
\text { Independent } \\
\text { Variables }\end{array}$ \\
\hline 20 & $\begin{array}{l}\text { Bonson and } \\
\text { Escobar } \\
(2006)\end{array}$ & $\begin{array}{l}\text { February } \\
2005 \text { to } \\
\text { March } 2005\end{array}$ & $\begin{array}{l}266 \\
\text { companies (13 } \\
\text { Eastern } \\
\text { European } \\
\text { countries) }\end{array}$ & 44 & Disclosure Index & $\begin{array}{l}\text { Activity sector (+) } \\
\text { Firm size (+) } \\
\text { Auditor firm (+) }\end{array}$ \\
\hline 21 & $\begin{array}{l}\text { Abdelsalam et } \\
\text { al. (2007) }\end{array}$ & $\begin{array}{l}\text { Single day in } \\
\text { mid-2005 }\end{array}$ & $\begin{array}{l}\text { London Stock } \\
\text { Exchange } \\
\text { (LSE) }\end{array}$ & 143 & $\begin{array}{l}\text { Corporate Internet } \\
\text { Reporting } \\
\text { Comprehensiveness: } \\
\text { 74-Content } \\
\text { 69-Usability }\end{array}$ & $\begin{array}{l}\text { Analyst following } \\
\text { Director holding } \\
\text { Director } \\
\text { independence } \\
\text { CEO duality }\end{array}$ \\
\hline 22 & $\begin{array}{l}\text { Abdelsalam } \\
\text { and El-Masry } \\
(2008)\end{array}$ & Not specified & $\begin{array}{l}44 \text { Irish } \\
\text { companies }\end{array}$ & 13 & Timeliness & $\begin{array}{l}\text { Board independence } \\
(+) \\
\text { Ownership structure } \\
(+)\end{array}$ \\
\hline 23 & $\begin{array}{l}\text { Barako et al. } \\
\text { (2008) }\end{array}$ & 2006 & $\begin{array}{l}\text { Jakarta Stock } \\
\text { Exchange } \\
\text { (JSX) }\end{array}$ & Not specified & Existence of firm website & $\begin{array}{l}\text { Firm size }(+) \\
\text { Age of companies } \\
(+)\end{array}$ \\
\hline 24 & $\begin{array}{l}\text { Ezat \& El- } \\
\text { Masry (2008) }\end{array}$ & $\begin{array}{l}\text { December } \\
2006\end{array}$ & $\begin{array}{l}37 \text { companies } \\
\text { (Cairo and } \\
\text { Alexandria } \\
\text { Stock } \\
\text { Exchange) }\end{array}$ & 11 & $\begin{array}{l}\text { Corporate Internet } \\
\text { Reporting Timeliness }\end{array}$ & $\begin{array}{l}\text { Size (+) } \\
\text { Type of business: } \\
\text { Service sector (+) } \\
\text { Liquidity (+) } \\
\text { Ownership structure } \\
(+) \\
\text { Board composition } \\
(+) \\
\text { Size of the board } \\
\text { directors (+) }\end{array}$ \\
\hline 25 & Almilia (2009) & $\begin{array}{l}\text { November } \\
2007 \text { and } \\
\text { February } \\
2008\end{array}$ & $\begin{array}{l}\text { Public listed } \\
\text { companies in } \\
\text { Indonesia } \\
\text { Stock } \\
\text { Exchange }\end{array}$ & Not specified & $\begin{array}{l}\text { Internet financial and } \\
\text { sustainability reporting } \\
\text { index }\end{array}$ & $\begin{array}{l}\text { Firm size (+) } \\
\text { Leverage (+) } \\
\text { Majority } \\
\text { shareholding (+) } \\
\text { Auditor size (+) } \\
\text { Industry type (+) }\end{array}$ \\
\hline 26 & $\begin{array}{l}\text { Al Arussi et al. } \\
\text { (2009) }\end{array}$ & Not specified & $\begin{array}{l}\text { Public listed } \\
\text { companies on } \\
\text { the Bursa } \\
\text { Malaysia }\end{array}$ & 60 & $\begin{array}{l}\text { Internet financial and } \\
\text { environmental disclosure } \\
\text { index } \\
\text { 24-Financial } \\
\text { 36-Environmental }\end{array}$ & $\begin{array}{l}\begin{array}{l}\text { Level of technology } \\
(+)\end{array} \\
\text { Ethnicity of CEO (+) } \\
\text { Firm size (+) } \\
\text { Existence of } \\
\text { dominant } \\
\text { personality, (-) with } \\
\text { financial disclosure } \\
\end{array}$ \\
\hline 27 & $\begin{array}{l}\text { Garg \& Verma } \\
(2010)\end{array}$ & January 2008 & $\begin{array}{l}200 \\
\text { companies of } \\
\text { BSE-200 Index }\end{array}$ & 119 & $\begin{array}{l}\text { Internet Disclosure Index } \\
\text { (IDI) }\end{array}$ & $\begin{array}{l}\text { Industry sector }(+) \\
\text { Size }(+) \\
\text { Business house }(+)\end{array}$ \\
\hline 28 & $\begin{array}{l}\text { Ali Khan } \\
(2010)\end{array}$ & $\begin{array}{l}\text { October } 2008 \\
\text { to December } \\
2008\end{array}$ & $\begin{array}{l}\text { Public listed } \\
\text { companies on } \\
\text { the Bursa } \\
\text { Malaysia }\end{array}$ & 87 & $\begin{array}{l}\text { Internet Financial } \\
\text { Reporting Index } \\
\text { 67- Content } \\
\text { 20- Presentation }\end{array}$ & $\begin{array}{l}\text { Firm size }(+) \\
\text { Listing age }(+) \\
\text { ROE }(+)\end{array}$ \\
\hline 29 & $\begin{array}{l}\text { Aly et al. } \\
\text { (2010) }\end{array}$ & $\begin{array}{l}\text { October } 2005 \\
\text { to January } \\
2006\end{array}$ & $\begin{array}{l}\text { Egyptian } \\
\text { Stock } \\
\text { Exchange }\end{array}$ & 90 & $\begin{array}{l}\text { Disclosure Index } \\
58 \text { - Content } \\
24 \text { - Presentation }\end{array}$ & $\begin{array}{l}\text { Profitability (+) } \\
\text { Foreign listing }(+) \\
\text { Industry sector: } \\
\text { communication and } \\
\text { financial sector }(+)\end{array}$ \\
\hline
\end{tabular}




\section{Explanatory Studies}

Most of early studies on IFR are descriptive in nature. Petravick and Gillett (1996) reported that $69 \%$ of the top 150 of Fortune 500 companies had websites and $54 \%$ of them made some form of financial information available on their websites. Louwers, Pasewark and Typpo (1996) found that approximately $23 \%$ of the top 150 Fortune 500 corporations include virtually all the information typically shown in a paper based annual report, on the web. Petravick and Gillett (1998) discovered that 99 $(79.2 \%)$ of the top 125 of the Fortune 500 companies published their earnings online simultaneously with an earnings announcements. Gowthrope and Amat (1999) analyzed the financial reporting on the Internet by a total of 379 firms quoted on the Madrid Stock Exchange and note that $19 \%$ of the firms disclose financial information on the web. Deller, Stubenrath and Weber (1999) reported that U.S. corporations were using the Internet for investor relations more extensively than their counterparts in the U.K. and Germany. Hedlin (1999) analyzed the web based investor relations activities of 60 companies listed on the Stockholm Stock Exchange in Sweden and found that $83 \%$ of the firms had financial reports on their websites.

Craven and Marston (1999) analyzed a sample of 2006 companies obtained from FTSE-100 index and from companies with high stock capitalization according to the Financial Times in January 1998. Findings included that 153 companies (74\%) had web pages, 67 companies (33\%) provided their accounts in detail, whereas 42 companies $(20 \%)$ only provided a summary.

Debreceny and Gray (1999) surveyed the corporate website of 45 large, listed U.K., German, and French companies to examine audit implication of electronic dissemination of financial information. Their findings raised significant issues regarding the format and usability of the information provided, such as: is the audit opinion safe from change by the client or related other party?, should the web-based auditor's report reside at the auditor's or the client's website?, what is the meaning of an audit report in a hyperlinked web environment?, should the auditor allow hypertext links to the auditor's report?, should the auditor allow hypertext links from the auditor's report?, home of the financial statements and the audit, auditor's report 'look and feel', and authority of the audit statements.

The disclosure of corporate information by Internet is attracting the attention not only of various accountings bodies but also researchers (Bonson \& Escobar, 2006). Several standard setters and professional groups have also sponsored IFR studies. These include the Institute of Chartered Accountants in England and Wales (ICAEW, 1998, 2004), the International Accounting Standards Committee (IASC) (Lymer et al., 1999), Canadian Institute of Chartered Accountants (CICA) (Trites, 1999), the U.S. Financial Accounting Standards Board (FASB, $2000,2004)$, and the International Federal of Accountants (IFAC, 2002).

\section{Relationship Studies}

While descriptive studies provide valuable insights into the studies of IFR, this probably would not explain the factors that influence the IFR. Therefore, several studies have been carried out to explain the factors that influence IFR. Research on IFR has produced valuable insights into the determinants of companies' Internet disclosure choice (Kelton \& Yang, 2008). Ashbaugh et al. (1999) document IFR practices and provide preliminary evidence on why some firms disseminate financial information on their corporate websites, while others do not. Ashbaugh et al. (1999) find that firms engaging in IFR are larger and more profitability than those not engaging in IFR. Furthermore, firms responding to their survey indicate that disseminating information to shareholders is an important reason for establishing an Internet presence. Ashbaugh et al. (1999) is one of the pioneer 
studies to investigate the IFR issue; however, it does not provide a theoretical rationale for its analysis.

Craven and Marston (1999) present the result of a survey of Internet reporting based on the top 200 UK companies. They find that larger companies are more likely to disclose information on their website, although industrial classification did not seem to be significant. Pirchegger and Wagenhofer (1999) find that whereas firm size and profitability affect the IFR of Austraian companies, they do not affect German companies' IFR choices. Joshi and Al-Bastaki (2000) survey the current state of Internet usage by a sample of 35 banks in Bahrain. Their study finds that large size banks have been using their websites of financial reporting purposes.

Debreceny et al. (2002) examine voluntary IFR in 22 countries to identify the firm and environment determinants of IFR. They used two dimensions (i.e., content and presentation) to measure the level of IFR. They find that presentation aspect of IFR is more associated with the level of technology and disclosure environment than the content of IFR. They also find that voluntary adoption of IFR in 22 countries is associated with company size and listing on an U.S stock exchange, but not associated with leverage, risk, or Internet penetration in the countries.

Xiao et al. (2004) measure IFR in four dimensions (i.e., content, presentation methods, mandatory items, and voluntary items) and analyze the determinants of Internet-based corporate disclosure by Chinese listed companies. They find that IFR is positively and significantly associated with the proportion of institutional ownership (also called legal person ownership), but not with ownership by domestic private investors, foreign investors, or the state. $\mathrm{Al}$ Arussi et al. (2009) find that level of technology, ethnicity of CEO and firm size are determinants of both internet financial and environmental disclosure.

More recently, Ali Khan (2010) also measure IFR in two dimensions (i.e., content and presentation) and analyzes the determinants of IFR by Malaysian listed companies. He finds that IFR is positively and significantly associated with firm size, listing age and return on equity. Furthermore, Aly et al. (2010) find that profitability, foreign listing and industrial sector (communications and financial services) are the most important factors that affect the amount and the presentation formats on the internet reporting in Egypt.

One characteristic of prior studies on IFR research is strong focus on the economic aspects of determinants of IFR (Kelton \& Yang, 2008). A number of studies investigate the association between IFR and factors such as firm size, profitability, leverage, etc. (Craven \& Marston, 1999; Debreceny et al., 2002; Ettredge et al., 2002; Oyelere et al., 2003).

After having an extensive literature review, this section concludes that the dimension of IFR had been defined in various and inconsistent ways. Consequently, the use of different dimensions of IFR construct creates problem and difficulties in integrating the existing knowledge. Table 2 show a summary of independence variables result of IFR research. 
Table 2: Summary of Independence Variables Results for IFR

\begin{tabular}{|c|c|c|c|}
\hline No. & $\begin{array}{l}\text { Independence } \\
\text { variables }\end{array}$ & Result & Researchers (Year) \\
\hline 1 & Firm size & $\begin{array}{l}\text { Significant } \\
(+)\end{array}$ & $\begin{array}{l}\text { Ali Khan (2010), Garg and Verma (2010), Al Arussi et al. } \\
\text { (2009), Abdelsalam and El-Masry (2008), Ezat and El- } \\
\text { Masry (2008), Kelton and Yang (2008), Ali Khan et al. } \\
\text { (2007), Bonson and Escobar (2006), Chan and } \\
\text { Wickramasinghe (2006), Pervan (2005), Hanifa and Ab. } \\
\text { Rashid (2005) - Total asset, Abdul Hamid and Md Salleh } \\
\text { (2005), Laswad et al. (2005), Marston and Polei (2004), } \\
\text { Mandes-da-Silva and Christenen (2004), Xiao et al. (2004), } \\
\text { Joshi and Al-Modhahki (2003), Marston (2003), Oyelere et } \\
\text { al. (2003), Ettredge et al. (2002), Debreceny et al. (2002), } \\
\text { Ismail (2002), Ashbaugh et al. (1999), Craven and Marston } \\
\text { (1999), Hassan et al.(1999), Pirchegger and Wagenhofer } \\
\text { (1999) (Austria: 1997,1998), }\end{array}$ \\
\hline \multirow[t]{2}{*}{2} & Type of industry & $\begin{array}{l}\text { Significant } \\
(+)\end{array}$ & $\begin{array}{l}\text { Aly et al. (2010) - Communication and financial sector, } \\
\text { Garg and Verma (2010), Bonson and Escobar (2006), Chan } \\
\text { and Wickramasinghe (2006) - Banking and manufacturing, } \\
\text { Abdul Hamid and Md Salleh (2005), Joshi and Al-Modhahki } \\
\text { (2003), Oyelere et al. (2003) }\end{array}$ \\
\hline & & $\begin{array}{l}\text { Not } \\
\text { significant }\end{array}$ & $\begin{array}{l}\text { Mohamed et al. (2009), Chan and Wickramasinghe (2006) - } \\
\text { Mining, Hanifa and Ab. Rashid (2005), Marston (2003), } \\
\text { Ismail (2002), Ismail and Tayib (2000), Hassan et al. } \\
\text { (1999), Craven and Marston (1999) }\end{array}$ \\
\hline \multirow[t]{3}{*}{3} & Audit firm & $\begin{array}{l}\text { Significant } \\
(+)\end{array}$ & Kelton and Yang (2008), Bonson and Escobar (2006) \\
\hline & & $\begin{array}{l}\text { Significant } \\
(-)\end{array}$ & Chan and Wickramasinghe (2006) \\
\hline & & $\begin{array}{l}\text { Not } \\
\text { significant }\end{array}$ & Joshi and Al-Modhahki (2003), Hassan et al. (1999) \\
\hline \multirow[t]{2}{*}{4} & Leverage & $\begin{array}{l}\text { Significant } \\
(+)\end{array}$ & $\begin{array}{l}\text { Hanifa and Ab. Rashid (2005), Laswad et al. (2005), Ismail } \\
\text { (2002) }\end{array}$ \\
\hline & & $\begin{array}{l}\text { Not } \\
\text { significant }\end{array}$ & $\begin{array}{l}\text { Al Arussi et al. (2009), Ezat dan El-Masry (2008), Ali Khan } \\
\text { et al. (2007), Chan and Wickramasinghe (2006), Mandes- } \\
\text { da-Silva and Christenen (2004), Oyelere et al. (2003), } \\
\text { Debreceny et al.(2002) }\end{array}$ \\
\hline \multirow[t]{3}{*}{5} & Profitability & $\begin{array}{l}\text { Significant } \\
(+)\end{array}$ & $\begin{array}{l}\text { Ali Khan (2010), Aly et al.(2010), Ali Khan et al. (2007), } \\
\text { Ismail (2002), Hassan et al. (1999) }\end{array}$ \\
\hline & & $\begin{array}{l}\text { Significant } \\
(-)\end{array}$ & Mandes-da-Silva and Christenen (2004) \\
\hline & & $\begin{array}{l}\text { Not } \\
\text { significant }\end{array}$ & $\begin{array}{l}\text { Al Arussi et al. (2009), Abdelsalam and El-Masry (2008), } \\
\text { Ezat and El-Masry (2008), Chan and Wickramasinghe } \\
\text { (2006), Momany and Al-Shorman (2006), Abdul Hamid and } \\
\text { Md Salleh (2005), Marston and Polei (2004), Xiao et al. } \\
\text { (2004), Marston (2003), Joshi and Al-Modhahki (2003), } \\
\text { Oyelere et al. (2003), Ashbaugh et al. (1999) }\end{array}$ \\
\hline No. & $\begin{array}{l}\text { Independence } \\
\text { variables }\end{array}$ & Result & Researchers (Year) \\
\hline
\end{tabular}




\begin{tabular}{|c|c|c|c|}
\hline \multirow[t]{3}{*}{6} & $\begin{array}{l}\text { Listing status / } \\
\text { foreiqn listing }\end{array}$ & $\begin{array}{l}\text { Significant } \\
(+)\end{array}$ & $\begin{array}{l}\text { Aly et al. (2010), Hanifa and Ab. Rashid (2005), Marston } \\
\text { and Polei (2004) for } 2003\end{array}$ \\
\hline & & $\begin{array}{l}\text { Significant } \\
(-)\end{array}$ & Debreceny et al. (2002) - IFR-P \\
\hline & & $\begin{array}{l}\text { Not } \\
\text { significant }\end{array}$ & $\begin{array}{l}\text { Xiao et al. (2004), Marston (2003), Oyelere et al. (2003), } \\
\text { Ismail and Tayib (2000) }\end{array}$ \\
\hline \multirow[t]{2}{*}{7} & Liquidity & $\begin{array}{l}\text { Significant } \\
(+)\end{array}$ & Ezat and El-Masry (2008), Oyelere et al. (2003) \\
\hline & & $\begin{array}{l}\text { Not } \\
\text { significant }\end{array}$ & Chan and Wickramasinghe (2006) \\
\hline 8 & Performance & $\begin{array}{l}\text { Not } \\
\text { significant }\end{array}$ & $\begin{array}{l}\text { Hanifa and Ab. Rashid (2005), Mandes-da-Silva and } \\
\text { Christenen (2004), Ettredge et al. (2002) - INDEX }\end{array}$ \\
\hline 9 & $\begin{array}{l}\text { Systematic risks } \\
\text { (BETA) }\end{array}$ & $\begin{array}{l}\text { Not } \\
\text { significant }\end{array}$ & $\begin{array}{l}\text { Chan and Wickramasinghe (2006), Marston and Polei } \\
\text { (2004), Joshi and Al-Modhahki (2003), Debreceny et al. } \\
\text { (2002) }\end{array}$ \\
\hline 10 & Growth & $\begin{array}{l}\text { Significant } \\
(+)\end{array}$ & Hanifa and Ab. Rashid (2005) \\
\hline 11 & Originality & $\begin{array}{l}\text { Not } \\
\text { significant }\end{array}$ & Bonson and Escobar (2006), Joshi and Al-Modhahki (2003) \\
\hline \multirow[t]{2}{*}{12} & $\begin{array}{l}\text { Ownership } \\
\text { structure }\end{array}$ & $\begin{array}{l}\text { Significant } \\
(+)\end{array}$ & $\begin{array}{l}\text { Ezat and El-Masry (2008), Marston and Polei (2004) for } \\
2000\end{array}$ \\
\hline & & $\begin{array}{l}\text { Significant } \\
(-)\end{array}$ & Oyelere et al. (2003) \\
\hline 13 & Free quoted & $\begin{array}{l}\text { Significant } \\
(+)\end{array}$ & Pervan (2005) \\
\hline 14 & Listing age & $\begin{array}{l}\text { Significant } \\
(+)\end{array}$ & Ali Khan (2010) \\
\hline 15 & $\begin{array}{l}\text { Foreign } \\
\text { ownership }\end{array}$ & $\begin{array}{l}\text { Not } \\
\text { significant }\end{array}$ & Abdul Hamid and Md Salleh (2005) \\
\hline 16 & $\begin{array}{l}\text { Shareholders' } \\
\text { ownership }\end{array}$ & $\begin{array}{l}\text { Significant } \\
(+)\end{array}$ & Hanifa and Ab. Rashid (2005) \\
\hline 17 & $\begin{array}{l}\text { Ethnicity of } \\
\text { chief executive } \\
\text { officer }\end{array}$ & $\begin{array}{l}\text { Not } \\
\text { significant }\end{array}$ & Al Arussi et al. (2009) \\
\hline 18 & $\begin{array}{l}\text { Total of share } \\
\text { issued }\end{array}$ & $\begin{array}{l}\text { Significant } \\
(+)\end{array}$ & Pirchegger and Wagenhofer (1999) \\
\hline 19 & $\begin{array}{l}\text { Number of } \\
\text { shareholders }\end{array}$ & $\begin{array}{l}\text { Not } \\
\text { significant }\end{array}$ & Breenan and Hourigan (1998) \\
\hline 20 & $\begin{array}{l}\text { Level of } \\
\text { technology }\end{array}$ & $\begin{array}{l}\text { Significant } \\
(+)\end{array}$ & Al Arussi et al. (2009), Debreceny et al. (2002) - IFR-P \\
\hline 21 & $\begin{array}{l}\text { Existence of } \\
\text { dominant } \\
\text { personalities }\end{array}$ & $\begin{array}{l}\text { Not } \\
\text { significant }\end{array}$ & Al Arussi et al. (2009) \\
\hline
\end{tabular}

\section{Timeliness of IFR}

Although many studies investigate the extent of IFR and its determinants, few studies focus on the timeliness (Ezat \& El-Masry, 2008). According to Abdelsalam and Street (2007), numerous studies examine the level of corporate internet reporting (CIR) and/or the determinants of IFR level of CIR: only few studies focus on timeliness. Pirchegger and Wagenhofer (1999) analyze five items in the dimension of timeliness: regular website 
updating, ability to distinguish current from older information, the availability of daily stock quotations, the response time to standard requests, and the response time to special requests. Pirchegger and Wagenhofer (1999) find that, on average, German and Austrian companies satisfy $66.3 \%$ of the five timeliness criteria studied.

Ettredge, Richardson and Scholz (2002) find an average delay of 30 days from U.S. companies file Form 10-K and the date Form $10-\mathrm{K}$ appears on the company website. Shorter delays are associated with greater profitability, shorter lags in announcing earnings through press releases, and the use of multiple file formats for Form $10-\mathrm{K}$ presentations. Longer delays are associated with external links to U.S. Security and Exchange Commission (SEC) dan Electronic Data Gathering, Analysis and Retrieval (EDGAR).

Moreover, two CIR studies focusing on timeliness were published in 2004. Oyelere et al. (2004)

identify growing user demands for increased timeliness of CIR. Davey and Homkajohn (2004) measure CIR timeliness and find that Thai companies perform better on user support and content than timeliness and technology. Ezat and El-Masry (2008) examine the key factors that affect the timeliness of IFR by Egyptian listed companies on the Cairo and Alexandria Stock Exchange. They find that a significant relationship between the timeliness of IFR and firms size, type of industry, liquidity, ownership structure, board composition and board size. Abdelsalam and El-Masry (2008) provide evidence of a link between timely IFR and the ownership structure characteristics of board independence and size.

\section{Conclusion}

This paper provides insights into the evolution of IFR research to contribute to the literature by reviewing and documenting the research of IFR. It is perhaps the conclusion of this paper that many are keen to see pointers for the direction of future empirical and more conclusive work in the IFR field.

Previous studies reveal that the trend of IFR researches starts from descriptive research, comparative research, association research, dimension and timeliness of IFR. As suggested by Ashbaugh et al. (1999), Oyelere et al. (2003), and Ali Khan and Ismail (2011), future research should develop a comprehensive predictive model for the choice of IFR. Furthermore, in line with the proposition before, changes in the IFR environment necessitate current examination and broader analysis of disclosure practices (Kelton \& Yang, 2008). Therefore, question such as determinants or factors underlying the influences for adopting practices needs more detailed examination and analyses. This situation will give an opportunity to further investigate the factors that influence the practice of IFR.

A comprehensive review of existing literature disclosure index indicates that different researchers used different dimensions to represent IFR disclosure index. These differences contribute to the variations in the findings among the researchers and thus are unable to clearly explain the phenomenon and the influence factors. Therefore, the dimension of IFR disclosure index has also become an important and an interesting agenda to be investigated. Based on extensive literature review, as mentioned by Ali Khan and Ismail (2010), and Ali Khan and Ismail (2011), it could be concluded that a more comprehensive and holistic reporting index using a relevant dimension is needed. Content dimension will reveal information on how to use latest display in disseminating a company corporate information and website design. Then, presentation dimension will supply information on the usage of the latest display criteria in disseminating corporate information and company's web design. 


\section{Acknowledgement}

The financial support for the authors' research from Minister of Higher Education (MOHE), Malaysia and Research Management Center (RMC), Universiti Teknologi Malaysia, Johor Bahru, Johor, Malaysia vote no. 77972 by Short Term Research Grant (New Academic Staff with PhD) also are appreciated.

\section{References}

Abdelsalam, O. H., Bryant, S. M. \& Street, D. L. (2007). "An Examination of Comprehensiveness of Corporate Internet Reporting Provided by London-Listed Companies," Journal of International Accounting Research, 6(2), 1-33.

Abdelsalam, O. H. \& El-Masry, A. (2008). "The Impact of Board Independence and Ownership Structure on the Timeliness of Corporate Internet Reporting of Irish-Listed Companies," Managerial Finance, 34(12), 907-918.

Abdelsalam, O. H., Street, D. L. \& Byrant, S. M. (2004). "Corporate Internet Reporting by BSE Sensex Companies," Indian Accounting Review, December 8(2), 1-18.

Abdelsalam, O. H. \& Street, D. L. (2007). "Corporate Governance and the Timeliness of Corporate Internet Reporting by U.K. Listed Companies," Journal of International Accounting, Auditing and Taxation, 16, 111130.

Abdul Hamid, F. Z. \& Md Salleh, M. S. (2005). "The Determinants of the Investor Relations Information in the Malaysian Companies' Website," Corporate Ownership \& Control, 3(1), 173-185.

Al Arussi, A. S., Selamat, M. H. \& Hanefah, M. M. (2009). "Determinants of Financial and Environmental Disclosures through the Internet by Malaysian Companies," Asian Review of Accounting, 17(1), 59-76.
Ali Khan, M. N. A. (2010). "Pelaporan Kewangan Menerusi Internet: Indeks, Tahap Pelaporan Dan Faktor Penentunya," Unpublished Phd Dissertation: Universiti Utara Malaysia, Sintok, Kedah.

Ali Khan, M. N. A. \& Ismail, N. A. (2010). “A Study on the Index of Internet Financial Reporting," International Postgraduate Business Journal, 2(1), 1-23.

Ali Khan, M. N. A. B. \& Ismail, N. A. (2011). "The Use of Disclosure Indices in Internet Financial Reporting Research," Journal of Global Business and Economics, 3(1), 157173.

Allam, A. \& Lymer, A. (2003). "Development in Internet Financial Reporting: Review and Analysis Across Five Developed Countries," the International Journal of Digital Accounting Research, 3(6), 165-199.

Almilia, L. S. (2009). "An Empirical Study of Factors in Influencing Internet Financial Reporting and Sustainability Reporting in Indonesia Stock Exchange," Paper Presented at Accounting \& Finance Association of Australia and New Zealand (AFAANZ) Conference 2009, Adelaide, July 5-7, 2009.

Aly, D., Simon, J. \& Hussainey, K. (2010). "Determinants of Corporate Internet Reporting: Evidence From Egypt," Managerial Auditing Journal, 25(2), 182-202.

Ashbaugh, H., Johnstone, K. M. \& Warfield, T. D. (1999). "Corporate Reporting on the Internet," Accounting Horizons, 13(3), 241257.

Barako, D. G., Rusmin, R. \& Tower, G. (2008). ' Web Communication: an Indonesian Perspective,' African Journal of Business Management, 2(3), 53-58.

Board, F. A. S. (2000). 'Business Reporting Research Project: Electronic Distribution of Business Reporting Information,' Steering Committee Report Series. Financial Accounting Standards Board. 
Bonson, E. \& Escobar, T. (2002). "A Survey on Voluntary Disclosure on the Internet: Empirical Evidence from 300 European Union Companies," the International Journal of Digital Accounting Research, 2(1), 27-51.

Bonson, E. \& Escobar, T. (2006). "Digital Reporting in Eastern European: an Empirical Study," International Journal of Accounting Information System, 7, 299-318.

Celik, O., Ecer, A. \& Karabacak, H. (2006). "Impact of Firm Specific Characteristics on the Web Based Business Reporting: Evidence from the Companies Listed in Turkey," Problems and Perspectives in Management, 4(3), 100-133.

Chan, W. K. \& Wickramasinghe, N. (2006). "Using the Internet for Financial Disclosure: the Australian Experience," International Journal Electronic Finance, 2(1), 118-150.

Chatterjee, B. \& Hawkes, L. (2008). "Does Internet Reporting Improve the Accessibility of Financial Inforamtion in Global World? a Comparative Study of New Zealand and Indian Companies," the Australian Business \& Finance Journal, 2(4), 33-56.

Craven, B. M. \& Marston, C. L. (1999). "Financial Reporting on the Internet by Leading UK Companies," the European Accounting Review, 8(2), 321-333.

Davey, H. \& Homkajohn, K. (2004). "Corporate Internet Reporting: an Asian Example," Problems and Perspectives in Management, 2, 211-227.

Davey, H. \& Homkajohn, K. (2004). "Corporate Websites, Design \& Disclosure: the Thailand Position," Malaysian Accounting Review, 3(1), 61-79.

Debreceny, R. \& Gray, G. L. (1999). "Financial Reporting on the Internet and the External Audit," the Eruropean Accounting Review, 8, 335-350.

Debreceny, R., Gray, G. L. \& Rahman, A. (2002). "The Determinants of Internet
Financial Reporting," Journal of Accounting and Public Policy, 21(4-5), 371-394.

Deller, D., Stubenrath, M. \& Weber, C. (1999). "A Survey on the Use of the Internet for Investor Relations in the USA, the UK and Germany," the European Accounting Review, 8(2), 351-364.

Ettredge, M., Richardson, V. J. \& Scholz, S. (2001). "The Presentation of Financial Information at Corporate Web Sites," International Journal of Accounting Information Systems, 2, 149-168.

Ettredge, M., Richardson, V. J. \& Scholz, S. (2002). "Dissemination of Information for Investors at Corporate Web Sites," Journal of Accounting and Public Policy, 21, 357-369.

Ezat, A. \& El-Masry, A. (2008). "The Impact of Corporate Governance on the Timeliness of Corporate Internet Reporting by Egyptian Listed Companies," Managerial Finance, 34(12), 848-867.

Gandia, J. L. (2008). "Determinants of Internet-Based Corporate Governance Disclosure by Spanish Listed Companies," Online Information Review, 32(6), 791-817.

Garg, M. C. \& Verma, D. (2010). “Web-Based Corporate Reporting Practices in India," the IUP Jorunal of Accounting Research \& Audit Practices, IX(3), 7-19.

Gowthorpe, C. \& Amat, O. (1999). "External Reporting of Accounting and Financial Information Via the Internet in Spain," the European Accounting Review, 8(2), 365-371.

Hassan, S., Jaffar, N., Johl, S. K. \& Mat Zain, M. (1999). 'Financial Reporting on the Internet by Malaysian Companies: Perceptions and Practices,' Asia-Pacific Journal of Accounting, 6(2), 299-319.

Hedlin, P. (1999). "The Internet as a Vehicle for Investor Relations: the Swedish Case," the European Accounting Review, 8(2), 373-381. 
IASC. (1999). "IASC Publishers Study of Business Reporting on the Internet," Press Release: International Accounting Standards Committee, 15 November 1999.

ICAEW. (1998). "The 21st Century Annual Reporting," London. the Institute of Chartered Accountants in England and Wales.

ICAEW. (2004). "Digital Reporting: a Progress Report," London. the Institute of Chartered Accountants in England and Wales.

IFAC. (2002, August). "Financial Reporting on the Internet," International Federation of Accountants.

Joshi, P. L. \& Al-Bastaki, H. (2000). "Factors Determining Financial Reporting on the Internet by Banks in Bahrain," the Review of Accounting Information Systems, 4(3), 63-74.

Joshi, P. L. \& Al-Modhahki, J. (2003). "Financial Reporting on the Internet: Empirical Evidence from Bahrain and Kuwait," Asia Review of Accounting, 11(1), 88-101.

Kelton, A. S. \& Yang, Y.-W. (2008). "The Impact of Corporate Governance on Internet Financial Reporting," Journal of Accounting and Public Policy, 27, 62-87.

Khadaroo, M. I. (2005). "Business Reporting on the Internet in Malaysia and Singapore: a Comparative Study," Corporate Communications: an International Journal, 10(1), 58-68.

Larran, M. \& Giner, B. (2002). "The Use of the Internet for Corporate Reporting by Spanish Companies," The International Journal of Digital Accounting Research, 2(1), 53-82.

Lodhia, S. K., Allam, A. \& Lymer, A. (2004). "Corporate Reporting on the Internet in Australia: an Exploratory Study," Australian Accounting Review, 14(3), 64-71.

Louwers, T. W., Pasewark, W. \& Typpo, E. (1996). "Silicon Valley Meets Norwalk," Journal of Accountancy, 186, 20-24.
Lybaert, N. (2002). “On-Line Financial Reporting: an Analysis of the Dutch Listed Firms," the International Journal of Digital Accounting Research, 2(4), 195-234.

Lymer, A., Debreceny, R., Gray, G. L. \& Rahman, A. (1999). Business Reporting on the Internet, IASC Research Report.

Marston, C. (2003). "Financial Reporting on the Internet by Leading Japanese Companies," Corporate Communication: an International Journal, 8(1), 23-34.

Marston, C. \& Leow, C. Y. (1998). 'Financial Reporting on the Internet by Leading UK Companies,' Paper Presented at the 21st Annual Congress of the European Accounting Association, Antwerp, Belgium.

Marston, C. \& Polei, A. (2004). "Corporate Reporting on the Internet by German Companies," International Journal of Accounting Information System, 5, 285-311.

Mendes-Da-Silva, W. \& Christensen, T. E. (2004, August). "Determinants of Voluntary Disclosure of Financial Information on the Internet by Brazilian Firms,"

Mohamed, E. K. A., Oyelere, P. \& Al-Busaidi, M. (2009). "A Survey of Internet Financial Reporting in Oman," International Journal of Emerging Markets, 4(1), 56-71.

Oyelere, P., Laswad, F. \& Fisher, R. (2003). "Determinants of Internet Financial Reporting by New Zealand Companies," Journal of International Financial Management and Accounting, 14(1), 26-61.

Pervan, I. (2006). "Voluntary Financial Reporting on the Internet- Analysis of the Practice of Stock-Market Listed Croatian and Slovene Joint Stock Companies," Financial Theory and Practice. 30(1), 1-27. travick, S. \& Gillett, J. W. (1996, July). "Financial Reporting on the World Wide Web," Management Accounting, 78(1), 26-29. 
Petravick, S. \& Gillett, J. W. (1998, October). 'Distributing Earnings Reports on the Internet,' Management Accounting, 80(4), 2629.

Pirchegger, B. \& Wagenhofer, A. (1999). "Financial Information on the Internet: a Survey of the Homepages of Austrian Companies," the European Accounting Review, 8(2), 383-395.

Trabelsi, S., Labelle, R. \& Laurin, C. (2004). "CAP Forum on E-Business: the Management of Financial Disclosure on Corporate Websites: a Conceptual Model," Canada Accounting Perspectives, 3(2), 235-259.

Trites, G. (1999). 'The Impact of Technology on Financial and Business Reporting,' Canadian Institute of Chartered Accountants.
Sanchez, I.-M. G., Dominguez, L. R. \& Alvarez, I. G. (2011). "Corporate Governance and Strategic Information on the Internet: a Study of Spanish Listed Companies," Accounting, Auditing \& Accountability Journal, 24(4), 471501.

Seetharaman, A. \& Subramaniam, R. (2005/2006). 'Navigating the Web of Financial Reporting,' European Business Forum, Winter, 23, 51-54.

Spanos, L. (2006, June). “Corporate Reporting on the Internet in a European Emerging Capital Market: The Greek Case,"

Xiao, J. Z., Yang, H. \& Chow, C. W. (2004). “The Determinants and Characteristics of Voluntary Internet-Based Disclosures by Listed Chinese Companies," Journal of Accounting and Public Policy, 23, 191-225. 